\title{
Current Role of Magnetic Resonance Imaging in Breast Imaging: A Primer for the Primary Care Physician
}

\author{
Shinil K. Shah, BS, Shiwan K. Shah, BS, and Kathleen V. Greatrex, MD
}

Magnetic resonance imaging (MRI) is a widely used imaging tool. Interest in the applicability of this modality in the realm of breast imaging has been steadily increasing over the past 25 years. The purpose of this article is to explore the use of contrast-enhanced MRI in breast imaging as it relates to the primary care physician. The mechanism, factors affecting image quality, basics of interpretation guidelines, and the uses and contraindications for this technique are explored. In addition, studies exploring the use of MRI in various areas of breast imaging are presented. It is hoped that the reader will become knowledgeable in the current utility of the tool as it relates to breast imaging. ( $\mathrm{J}$ Am Board Fam Pract 2005;18:478-90.)

Magnetic resonance imaging (MRI) has revolutionized many areas of body imaging. As a noninvasive, nonirradiating imaging tool, interest has steadily been developing as to the specific role of MRI in breast imaging, and whether this modality can assist with early detection and hopefully subsequently decrease the mortality of breast cancer.

Mammography has long been used for early detection of and screening for breast cancers. With optimal technique and patient conditions, it has a reported sensitivity between $69 \%$ and $90 \%$ and a specificity between $10 \%$ and $40 \%$. Many factors, including density of breast tissue (ie, younger patients, implants, and post surgical state) can affect these values. Ultrasound has been used as an adjunct to mammography, with particular value in differentiating cystic from solid lesions and in facilitating guided biopsy of suspicious areas. However, ultrasound has limitations, including the possibility of missing microcalcifications [associated with ductal carcinoma in situ (DCIS)] and difficulty

Submitted 28 March 2005; revised 1 July 2005; accepted 26 July 2005.

From the University of Medicine and Dentistry of New Jersey, School of Osteopathic Medicine, Stratford, NJ (Shinil K. Shah, Shiwan K. Shah); and Director of Breast Imaging, Department of Radiology, Our Lady of Lourdes Medical Center, Camden, NJ (KVG).

Conflict of interest: none declared.

Corresponding author: Shinil K. Shah, BS, 1510 Cherrywood Apartments, Clementon, NJ 08021 (e-mail: shahs7@ umdnj.edu). in ensuring that the entire breast was imaged with the transducer. ${ }^{1}$

Mammography alone is believed to miss between $10 \%$ and $30 \%$ of all breast cancers. Possible reasons may include density of breast parenchyma (as mentioned above), poor technique and positioning, error by the reading radiologist, and slow growing breast cancers. Although certain strategies, such as computer-aided detection (CAD) and/or rereading by another radiologist has been used in some cases, the impact on detection of breast cancer is variable. ${ }^{2,3}$

\section{History}

Contrast-enhanced MRI, which began to be used in the area of breast imaging in the 1980s, demonstrated a high sensitivity for invasive cancers. Other noted benefits included the ability for 3-dimensional imaging and the fact that imaging was not as limited by dense tissue. It was noted that this modality was able to detect cancers in which the screening mammogram was negative. Excitement generated by these preliminary findings led to a plethora of clinical pilot studies in the 1990s, with results that demonstrated the expanded value of MRI in breast imaging, including promise in the detection of early invasive breast cancer in high risk women. ${ }^{4}$ Over 20,000 patients have been studied in Europe and the United States, and it is believed that MRI is the most sensitive method to detect 
invasive breast cancer and that it can detect lesions in mammographically negative patients in up to $37 \%$ of cases. ${ }^{5,6}$

\section{Mechanism of Action}

T1- and T2-weighted MRI images alone are not useful for the screening or diagnosis of breast cancer. Although breast lesions would be able to be visualized on MRI, the differences in T1 and T2 with regard to benign and malignant changes is not significant, and therefore, one would get many false positives. However, contrast-enhanced MRI has been shown to assist with the differentiation of benign and malignant lesions because of tumormediated angiogenesis. ${ }^{1}$ The contrast agents used are gadolinium chelates. [As opposed to the contrast agents used in computerized axial tomography scanning, these agents are not iodine based. Some believe that there may be decreased nephrotoxicity with these agents, although there have been reports of such side effects. As such, renal failure is a relative contraindication, as well as pregnancy and breastfeeding. ${ }^{7-10}$ ]

Generally, for tumors to grow more than 2 to 3 $\mathrm{mm}$ in size, they have to secrete proangiogenic factors. Higher grade tumors are usually associated with increased vascularity. Most breast cancers will show increased enhancement $(70 \%$ or greater increase in signal intensity) within 5 minutes of administration of intravenous gadolinium. The degree of enhancement is thought to be proportional to the vascularity and hence the suspected grade of the tumor. ${ }^{2,5}$

Benign tumors, however, may also enhance. By taking note of the enhancement as a function of time, one can distinguish, in many cases, between benign and malignant lesions. The microvasculature of malignant lesions tends to be more haphazard, with increased capillary permeability and connections between the arteriolar and venular systems, bypassing the capillaries (ie, arteriovenous shunts). This leads not only to quicker enhancement but also quicker washout times, ie, the time it takes for clearance of the contrast material from the lesion.

Some have categorized the enhancement intensity versus time curve into 3 groups. Type I curves are characterized by a gradual increase in enhancement over time. This is supportive of a benign lesion. Type II curves are characterized by a rise in enhancement intensity followed by a plateau and can represent either benign or malignant lesions. Type III curves are the classic washout curves; a rapid rise in enhancement followed by a decreased intensity of enhancement, usually indicating malignancy. ${ }^{11}$

It is important to recognize caveats to the enhancement guidelines above. DCIS lesions are more commonly missed on MRI. This is due in part to the fact that DCIS lesions are less dependent on angiogenesis because they can get their nutritional supply via diffusion. Hence, DCIS lesions are less likely to enhance compared with other types of breast cancers. Furthermore, comedocarcinoma variants of DCIS are more likely to enhance than other subtypes. The histology of comedocarcinoma implies that central necrosis is occurring, hence impairing the nutritional supply. Increased angiogenesis is therefore required for further growth. ${ }^{1,11}$ The other major caveat is that these are general guidelines-benign lesions may sometimes resemble type III curves, whereas malignant lesions may resemble type I curves.

\section{Quality of Results}

There are several factors that influence the accuracy and quality of MR imaging of the breast.

\section{Technique}

One of the most important factors in enhancing the sensitivity of MRI of the breast has to do with technique. A few simple steps can dramatically improve the quality of the images obtained. The use of dedicated breast coils is one of these means (Figure 1). It is preferable to use a double breast coil as opposed to using a single coil to image both breasts. The coils apply gentle compression on the medial and lateral surfaces of the breast to decrease motion artifact. The breast should be placed in the center of the coil. Another factor that reduces artifact is the positioning of the patient. The patient should be prone, as this decreases the amount of respiratory motion artifact. The breast should be pulled as far away from the chest wall as possible. ${ }^{1,5,11}$

\section{Slice Thickness}

It is important to be able to measure lesions that are $\geq 5 \mathrm{~mm}$. Therefore, the slice thickness should be less than that, otherwise, one may have partial 


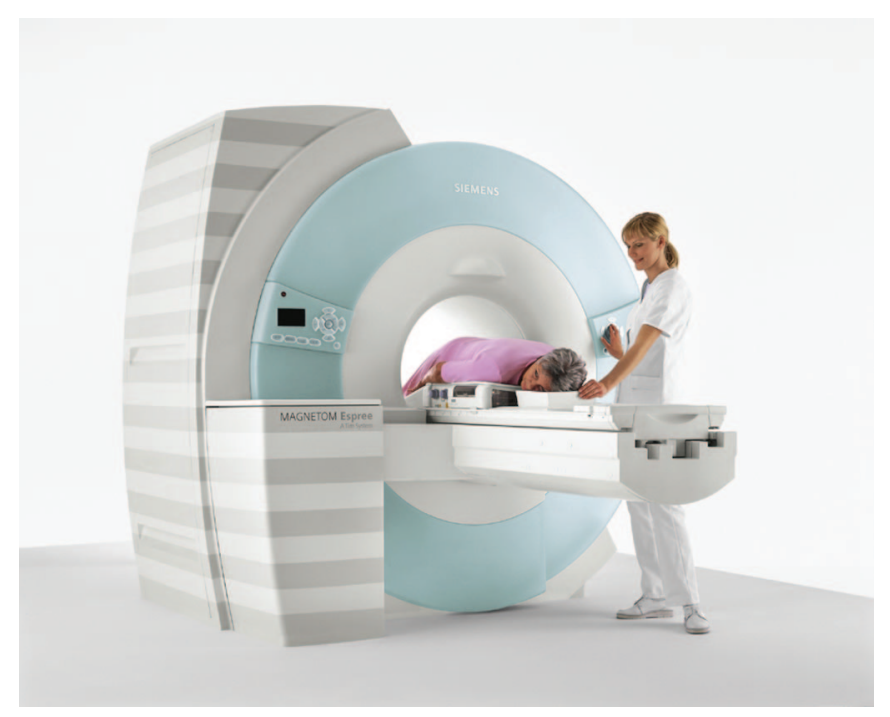

Figure 1. MR scanning of a patient using a dedicated breast coil

viewing of the lesion. To adequately visualize these lesions, the slice thickness must be between 2 and 4 $\mathrm{mm}$ with no gaps between the slices. Slice thickness also affects resolution, with smaller thickness parameters (ie, $<2$ to $3 \mathrm{~mm}$ ) leading to increased resolution and improved detection rates, especially of early cancers, which can grow along ducts in the breast with a diameter of only 1 to $2 \mathrm{~mm} .{ }^{1,5}$

\section{Fat Supression}

Fat suppression is an important aspect to MRI of the breast, even whereas many of the patients who have MRI may be younger and thus have a decreased proportion of fat tissue (stromal tissue is replaced by fat as patients age). ${ }^{12}$ High fat density can obscure areas of contrast enhancement. There are several methods of fat suppression. One is image subtraction (ie, subtracting the precontrast image from the postcontrast image), which can be helpful in subtracting the fat signal. However, this requires absolutely no patient movement between the precontrast and postcontrast images. If there is patient movement, the resulting image quality will be unacceptable. ${ }^{13}$ Other potential mechanisms of fat subtraction include automatic or manual chemical suppression in which the signal strength of the fat is detected automatically or manually by the operator and removed from the image.

\section{Speed}

The speed of image acquisition is important in breast MRI. It is important to obtain postcontrast injection images within 1 to 4 minutes to differentiate potential malignant uptake from delayed enhancement of normal glandular tissue. This is because normal breast tissue enhances over approximately 10 minutes; therefore by 10 minutes, it may be difficult to detect a cancerous lesion. ${ }^{1}$ This seems to compete with the need for increased spatial/image resolution (to increase the sensitivity of detection), which increases the time of imaging. However, with increases in field strength and rapid gradients, it is becoming increasingly possible to obtain adequate spatial and temporal resolution quality. ${ }^{13}$ Some ultra-fast protocols have achieved sensitivities of $95 \%$ and specificities of $86 \%$. However, these protocols have a much lower sensitivity for the detection of low grade DCIS. ${ }^{14}$

\section{Timing of the MRI and the Menstrual Cycle}

The ideal time for MRI of the breast is approximately between day 5 and 15 of the menstrual cycle,${ }^{5}$ because the luteal phase of the menstrual cycle with the associated increase in estrogen and progesterone leads to the stroma being edematous with development of the lobules. ${ }^{1}$ This leads to increased enhancement during the luteal stage of the menstrual cycle, with the enhancement being maximal 7 days before menstruation. ${ }^{1}$ Therefore, breast MRI should not be performed during this time, but rather, between day 5 and 15 , long enough after the luteal phase to decrease any residual enhancement. 


\section{Guidelines for Interpretation}

The interpretation of breast MRI has been standardized to some degree by the Lesion Diagnosis Working Group Project. ${ }^{15}$ Interpretation of MRI images depends on 2 factors, the morphology and the margins. The lesion may be described as round, oval, lobulated, irregular, or stellate. The margins of the lesion may be described as smooth, scalloped, irregular, or spiculated. Margins that are smooth are associated with a $95 \%$ negative predictive value for carcinoma, ie, they are probably benign. Lobulated margins have a $90 \%$ negative predictive value for carcinoma. On the other hand, irregular margins are associated with an $81 \%$ positive predictive value for malignancy, and spiculated margins are associated with a $90 \%$ positive predictive value for malignancy. ${ }^{11}$

The second part of the interpretation is the pattern of enhancement. The pattern of enhancement may be described as homogenous, heterogeneous, rim pattern (ie, peripheral enhancement), enhancing internal separations, or nonenhancing internal separations. In addition, one may have foci of enhancement, ie, a small area of enhancement without any mass or space occupying lesion. This may or may not represent an area of malignancy. ${ }^{11}$ Linear enhancement may suggest DCIS. Nonenhancing masses as well as masses with nonenhancing septations can also be present, but these tend to be benign lesions. Analyzing lesions by morphology, margins, and patterns of enhancement is sometimes referred to as morphologic analysis.

The third part of the interpretation, as mentioned above, is the enhancement intensity versus time curve, with malignant tumors tending to have fast enhancement with fast washout, and with benign lesions tending to have a gradual increase in enhancement. Analysis of breast MRI using these factors is sometimes referred to as kinetic or dynamic analysis.

\section{Limitations of MRI in Breast Imaging}

Some of the limitations of the use of MRI in breast imaging were alluded to earlier. These include the enhancement with the luteal phase of the menstrual cycle. In addition, the use of hormone therapy in postmenopausal women may lead to enhancement. Enhancement may be either focal or diffuse. In such cases, it may be necessary to repeat the MRI examination 2 or 3 months after stopping hormone therapy to obtain optimal results. ${ }^{1,5}$
Another limitation of MRI is that in some instances, various benign conditions of the breasts can be difficult to distinguish from malignant lesions-in other words, the guidelines are not clearcut. Such processes as fibrocystic disease of the breast, fibroadenomas, sclerosing adenosis, atypical hyperplasia, lobular carcinoma in situ (LCIS), and breast papillomas can all produce contrast enhancement patterns that are hard to distinguish from malignant processes. In addition, some benign processes such as proliferative dysplasia, inflammation, wounds, and benign tumors can enhance in a similar fashion to malignant tumors. MRI should not be performed on those patients who have known benign breast tumors or proliferative changes that would show an enhancement pattern on MRI. ${ }^{1,5,11}$

Furthermore, MRI may miss some cancers, especially ductal carcinoma in situ and invasive lobular cancers. The sensitivity of MRI for DCIS varies depending on the study, but ranges from $40 \%$ to $100 \%$. $^{1}$ There are various reasons for the variable sensitivity, some of which were alluded to earlier. This includes the fact that DCIS may be able to rely on nutrition through diffusion and therefore is able to rely less on proangiogenic factors until they are larger. DCIS often presents on mammography as microcalcifications, which MRIs do not detect. Because of the problem of MRI detecting DCIS, MRI does not necessarily help to narrow the differential when microcalcification is identified on mammography. These patients should therefore proceed straight to stereotactic biopsy. DCIS is frequently picked up on mammography because of microcalcifications. ${ }^{1,5,14,16}$ Invasive lobular carcinoma is another type of breast cancer that may be more difficult to detect on MRI than other types of breast cancers. ${ }^{14}$

The use of MRI after breast surgery is valuable in that it may help detect residual cancers in patients with positive margins as well as cancers originating at the lumpectomy site (which is where most recurrent cancers originate from) better than with conventional mammography. This is primarily caused by limitations secondary to scar formation. However, the inflammation and subsequent formation of granulation tissue at the scar site leads to an enhancement pattern on MRI that would be difficult to differentiate from a possible recurrence. Therefore, the recommendation is that an MRI should not be performed until at least 1 month after 
surgery to reduce the number of false positive results. ${ }^{14,16}$

With MRI of the breast after irradiation therapy, the inflammation associated with the radiation therapy leads to enhancement of the tissue. It is not possible to distinguish between postirradiation enhancement and tumor until approximately 9 months, and may be difficult in some patients until 18 months. ${ }^{14}$ One should therefore wait at least 9 months, at which most of the breast tissue that would have enhanced earlier would have been replaced by fibrosis.

MRI is also useful to assess responses to neoadjuvant and/or primary chemotherapy. However, it should be noted that MRI tends to underestimate the residual tumor. This may be because of chemotherapy induced decreases in vasculature and permeability, leading to decreased and/or altered patterns of enhancements. However, as noted below, MRI is still useful in this situation because MRI can detect an insufficient response earlier than other modalities.

In patients with mammographically identified lesions that are easily accessible to core biopsy, those patients should also proceed straight to biopsy. Core biopsy has a similar sensitivity but higher specificity when compared with MRI. There is also a notable cost difference between these 2 procedures.

\section{Current Uses of MRI in Breast Imaging Methods}

To identify specific clinical studies involving the various uses of MRI in breast imaging, the authors searched MEDLINE using the search terms listed in Table 1. Preference was given to prospective studies, and case studies were excluded.
Staging of Breast Cancer/Involvement of Pectorals

A number of studies (Table 2) have examined the utility of MRI in staging patients who have known breast cancer. ${ }^{17-24}$ In patients with already diagnosed breast cancer, the use of MRI may help to provide optimal therapy for patients. MRI has been shown to be more accurate compared with mammography or ultrasound in detecting the size and extent of the lesion. ${ }^{16}$ In addition, MRI is useful in the identification of multicentric disease, which may have an impact on the type of therapy, eg, radical mastectomy versus more conservative surgery.

The sensitivity of MRI in detecting multicentric disease ranges from approximately $89 \%$ to $100 \%$ with bilateral imaging to $95 \%$ to $100 \%$ with unilateral imaging. The specificity of excluding multicentric disease ranges from $82 \%$ to $97 \%$. Note that the specificity of MRI for multicentricity is actually less than mammography, meaning that there are more false positives. ${ }^{1,5,16}$

MRI is helpful in detecting pectoral muscle and chest wall involvement of breast cancer. Although involvement of the pectoral muscle does not increase the stage from T3 (T4 is when the serratus or intercostals muscles are involved), it might affect surgical therapy. Nipple involvement, which is important to know when planning subcutaneous mastectomy or breast conserving surgery, can also be clarified with MRI. Ohmenhauser demonstrated a sensitivity of $80 \%$ with regards to MRI identification of nipple involvement. ${ }^{16}$

\section{Residual/Recurrent Disease after Treatment}

MRI is useful for detection of residual disease after treatment (Table 3). ${ }^{25-43}$ The authors cite a number of studies demonstrating the value of MRI in this arena of imaging. MRI has been shown to be more sensitive and more specific (in certain studies)

Table 1. Major Applications of MRI in Breast Imaging

\begin{tabular}{|c|c|}
\hline Applications & MEDLINE Search Terms \\
\hline $\begin{array}{l}\text { Staging of breast cancer (including determining involvement } \\
\text { of pectoral musculature) }\end{array}$ & Magnetic resonance imaging AND breast cancer staging \\
\hline Determination of recurrent/residual disease after treatment & $\begin{array}{l}\text { Magnetic resonance imaging AND breast cancer AND } \\
\text { residual disease }\end{array}$ \\
\hline $\begin{array}{l}\text { Determination of occult breast cancer (especially in patients } \\
\text { with negative mammograms) }\end{array}$ & $\begin{array}{l}\text { Magnetic resonance imaging AND breast cancer AND } \\
\text { unknown primary }\end{array}$ \\
\hline $\begin{array}{l}\text { Possible use as a screening tool in patients at high risk for } \\
\text { breast cancer }\end{array}$ & $\begin{array}{l}\text { Magnetic resonance imaging AND breast cancer AND } \\
\text { high risk }\end{array}$ \\
\hline
\end{tabular}


Table 2. MRI in Staging of Breast Cancer

\begin{tabular}{|c|c|c|c|c|}
\hline Study & Type of Study & Study Population & $\mathrm{N}$ & Major Findings/Comments \\
\hline Boetes et al. ${ }^{23}$ & Retrospective & $\begin{array}{l}\text { Patients with invasive } \\
\text { lobular carcinoma } \\
\text { treated surgically }\end{array}$ & $\begin{array}{l}34 \text { (36 cases of } \\
\text { breast cancer) }\end{array}$ & $\begin{array}{l}\text { False negative rate for MRI was } 0 \% \\
\text { compared with } 3 \% \text { and } 14 \% \text { for US and } \\
\text { XRM, respectively; when } 2 \text { radiologists } \\
\text { retrospectively reviewed the exam results, } \\
\text { the percentage of correctly identified size } \\
\text { of cancer was } 47 \% \text { and } 75 \% \text { for MRI }(r= \\
0.81, P<.01) \text {; this was the most accurate } \\
\text { and most highly correlated method }\end{array}$ \\
\hline Schelfout et al. ${ }^{17}$ & Prospective & $\begin{array}{l}\text { Women with lesions on } \\
\text { XRM, US, and/or } \\
\text { CBE }\end{array}$ & 212 & $\begin{array}{l}96 \%, 37 \% \text {, and } 41 \% \text { of multifocal disease } \\
\text { was detected by MRI, XRM, and US, } \\
\text { respectively; } 95 \%, 18 \% \text {, and } 9 \% \text { of } \\
\text { multicentric disease was detected by MRI, } \\
\text { XRM, and US, respectively; } 100 \% \text { of } \\
\text { bilateral breast cancers were seen on MRI; } \\
56 \% \text { of bilateral breast cancers were seen } \\
\text { on XRM and US }\end{array}$ \\
\hline $\begin{array}{l}\text { Van Goethem } \\
\text { et al. }{ }^{24}\end{array}$ & Prospective & $\begin{array}{l}\text { Patients with dense } \\
\text { breasts planning to } \\
\text { undergo surgery }\end{array}$ & 67 & $\begin{array}{l}\text { 65/67 patients had breast cancer confirmed } \\
\text { pathologically; MRI was } 98 \% \text { sensitive for } \\
\text { initial lesion compared with } 83 \% \text { and } \\
70.8 \% \text { for XRM and US, respectively; } \\
\text { extent of cancer was underestimated by } \\
12.5 \% \text { of MRI results as opposed to } 37 \% \\
\text { and } 40 \% \text { for XRM and US results, } \\
\text { respectively; multifocal/multicentric } \\
\text { disease was picked up } 100 \% \text { of the time } \\
\text { by MRI as opposed to } 35 \% \text { and } 30 \% \text { of } \\
\text { XRM and US, respectively }\end{array}$ \\
\hline Bedrosian et al. ${ }^{18}$ & Retrospective & $\begin{array}{l}\text { Patients diagnosed with } \\
\text { invasive breast cancer } \\
\text { who had MRI } \\
\text { preoperatively }\end{array}$ & 267 & $\begin{array}{l}\text { MRI was } 95 \% \text { sensitive for detecting } \\
\text { primary breast cancer; planned } \\
\text { management of } 26 \% \text { of patients }(\mathrm{N}=69) \\
\text { were changed due to MRI results-in } 49 / \\
69(71 \%) \text { of the patients, postsurgical } \\
\text { pathology confirmed that the change in } \\
\text { management was appropriate }\end{array}$ \\
\hline Rieber et al. ${ }^{28}$ & Prospective & $\begin{array}{l}\text { Patients suspected of } \\
\text { having breast } \\
\text { malignancy based on } \\
\text { results of XRM, US, } \\
\text { or CBE }\end{array}$ & 43 & $\begin{array}{l}\text { Sensitivity of MR mammography for } \\
\text { diagnosis of primary cancer, contralateral } \\
\text { cancer, and multifocal disease was } 100 \% \text {, } \\
100 \% \text {, and } 95.2 \% \text {; similar values were } \\
93 \%, 100 \% \text {, and } 92.5 \% \text { for PET, } \\
\text { respectively }\end{array}$ \\
\hline Fischer et al. ${ }^{20}$ & Prospective & $\begin{array}{l}\text { Patients with breast } \\
\text { abnormalities after } \\
\text { XRM, CBE, PE, and } \\
\text { US }\end{array}$ & 463 & $\begin{array}{l}66 \text { patients }(14.3 \%) \text { had their planned } \\
\text { therapy accurately changed as a result of } \\
\text { MRI of the breast with } 16 \text { patients }(3.5 \%) \\
\text { undergoing unneeded open biopsy }\end{array}$ \\
\hline Esserman et al. ${ }^{21}$ & Prospective & $\begin{array}{l}\text { Patients with breast } \\
\text { cancer with planned } \\
\text { surgical correction }\end{array}$ & $\begin{array}{c}57 \text { (58 cases of } \\
\text { breast cancer) }\end{array}$ & $\begin{array}{l}\text { Preoperative MRI identified degree of } \\
\text { disease accurately in } 54 / 58 \text { cases of breast } \\
\text { cancer; anatomic detail identified on MRI } \\
\text { was accurate } 98 \% \text { of the time whereas } \\
\text { anatomic detail identified on XRM was } \\
\text { accurate in } 55 \% \text { of cases }\end{array}$ \\
\hline Rodenko et al. ${ }^{22}$ & Retrospective & $\begin{array}{l}\text { Patients with infiltrating } \\
\text { lobular carcinoma } \\
\text { who had MRI and } \\
\text { XRM performed } \\
\text { preoperatively }\end{array}$ & 20 & $\begin{array}{l}\text { Postoperative pathology correlated with } \\
\text { preoperative MRI findings in } 85 \% \text { of } \\
\text { patients; The correlation with } \\
\text { preoperative XRM was } 32 \%(P<.0001)\end{array}$ \\
\hline
\end{tabular}

than other imaging modalities, and has been shown to more accurately correlate with post surgical pathology. As stated above, MRI should be done at least 1 month after surgery to reduce false positives due to enhancement caused by granulation tissues. MRI can also be used to diagnose recurrent disease after breast conserving surgery and irradiation, whereas one would ideally have to wait at least 9 months. MRI is also useful in early detection of residual disease after chemotherapy. ${ }^{1,5,16}$

Fischer et al compared 2 groups of patients, one who had MRI before surgery and the other group 
Table 3. MRI in the Evaluation of Residual Disease

\begin{tabular}{|c|c|c|c|c|}
\hline Study & Type of Study & Study Population & $\mathrm{N}$ & Major Findings/Comments \\
\hline Yeh et al. ${ }^{25}$ & Prospective & $\begin{array}{l}\text { Patients with stage IIb/III breast } \\
\text { cancer undergoing neoadjuvant } \\
\text { chemotherapy (doxorubicin and } \\
\text { paclitaxel) }\end{array}$ & 31 & $\begin{array}{l}\text { Correlation with pathology } \\
\text { Equal to pathology/underestimate/overestimate } \\
\text { MRI: } 71 \% / 23 \% / 6 \% \\
\text { XRM: } 26 \% / 52 \% / 23 \% \\
\text { US: } 35 \% / 52 \% / 13 \% \\
\text { MRI was best correlated with pathology } \\
(P<.002)\end{array}$ \\
\hline Chen et al. ${ }^{26}$ & Prospective & $\begin{array}{l}\text { Patients with locally advanced } \\
\text { breast cancer receiving } \\
\text { neoadjuvant therapy } \\
\text { (adriamycin, cytoxan, and } \\
\text { paclitaxel) }\end{array}$ & 15 & $\begin{array}{l}\text { MRI tended to overestimate tumor response; for } \\
\text { partial non-responders MRI correlated with } \\
\text { pathology } 0 \% \text { of the time compared with } \\
17 \% \text { for CBE and } 83 \% \text { for PET; however, } \\
\text { for responders, MRI correlated with } \\
\text { pathology } 90 \% \text { of the time, with } 70 \% \\
\text { correlation for CBE and } 90 \% \text { for PET; MRI } \\
\text { size measurements of residual tumors did } \\
\text { correlate with pathology (coefficient } 0.7 \\
\text { compared with }-0.06 \text { for CBE) }\end{array}$ \\
\hline Denis et al. ${ }^{27}$ & Prospective & $\begin{array}{l}\text { Patients with locally advanced } \\
\text { breast cancer receiving } \\
\text { neoadjuvant therapy with either } \\
5 \text {-5-fluorouracil/epirubicin/ } \\
\text { cyclophosphamide; docetaxel } \\
\text { only, or docetaxel with } \\
\text { epirubicin }\end{array}$ & 40 & $\begin{array}{l}\text { Correlation coefficient of MRI measurements } \\
\text { with pathology: 5-fluorouracil/E/C: } 0.89 \text {, } \\
\text { DXL: } 0.64 \text {, DXL/E: 0.16 MRI overestimated } \\
\text { tumor response in DXL-based groups, which } \\
\text { was believed to be due to antiangiogenic } \\
\text { effect of DXL, which would impair MRI } \\
\text { contrast enhancement; this was supported by } \\
\text { the fact that DXL-based groups had residual } \\
\text { disease of microscopic nests of tumor cells on } \\
\text { pathology as opposed to single nodular } \\
\text { lesions }\end{array}$ \\
\hline Tozaki et al. ${ }^{28}$ & Prospective & $\begin{array}{l}\text { Patients with locally advanced } \\
\text { breast cancer (IIb/III) } \\
\text { undergoing neoadjuvant } \\
\text { chemotherapy }\end{array}$ & 19 & $\begin{array}{l}\text { Accuracy (deviation from pathology of less than } \\
2 \text { mm) of late phase CT and MRI scans (scan } \\
4 \text { minutes after contrast injection) compared } \\
\text { with pathology was up to } 90 \% \text { for DCIS and } \\
\text { replaced (diffuse pre-NAC contrast } \\
\text { enhancement) lesions and } 88 \% \text { for } \\
\text { nonreplaced (localized CE) lesions; early } \\
\text { phase scans were } 0 \% \text { accurate for } \\
\text { DCIS/replaced and } 75 \% \text { accurate for } \\
\text { nonreplaced lesions }\end{array}$ \\
\hline Bodini et al. ${ }^{29}$ & Prospective & $\begin{array}{l}\text { Patients with } \mathrm{T} 2 \text { to } 4, \mathrm{~N} 0 \mathrm{M} 0 \\
\text { breast cancer treated with } 3 \text { to } \\
4 \text { cycles of epirubicin }\end{array}$ & 79 & $\begin{array}{l}\text { Clinical response correlation with pathology } \\
\text { correlation coefficients were } 0.72 \text { for MRI } \\
\text { and } 0.68 \text { for CBE }\end{array}$ \\
\hline Warren et al. ${ }^{30}$ & Retrospective & $\begin{array}{l}\text { Patients undergoing neoadjuvant } \\
\text { therapy }\end{array}$ & 67 & $\begin{array}{l}\text { MRI was more sensitive and specific for } \\
\text { assessment of complete or partial response } \\
\text { (100\% and } 80 \% \text { ) than conventional } \\
\text { assessment methods (CAM), including XRM, } \\
\text { US, and CBE ( } 98 \% \text { and } 50 \% \text { ); agreement } \\
\text { with pathology was marginally higher in MRI } \\
\text { compared with CAM ( } 81 \% \text { compared to } \\
68 \%, P=.09) ; \text { MRI increased diagnostic } \\
\text { knowledge in } 70 \% \text { of patients, and increased } \\
\text { diagnostic confidence in } 52 \% \text {; however, MRI } \\
\text { did not change treatment plan, decreased } \\
\text { confidence in } 20 \% \text { of patients, and decreased } \\
\text { knowledge in } 17 \% \text {; MRI tended to } \\
\text { overestimate response }\end{array}$ \\
\hline Lee et al. ${ }^{31}$ & Retrospective & $\begin{array}{l}\text { Patients who had excisional biopsy } \\
\text { who required definitive surgery, } \\
\text { eg, because of positive margins/ } \\
\text { residual disease and were } \\
\text { candidates for breast } \\
\text { conservation }\end{array}$ & 80 & $\begin{array}{l}\text { MRI sensitivity and specificity for residual } \\
\text { disease was } 61.2 \% \text { and } 69.7 \% \text {, respectively; } \\
\text { additional lesions were detected by imaging of } \\
\text { which } 10 \text { were only seen on MRI; of these, } 5 \\
\text { were benign, } 5 \text { were malignant; MRI changed } \\
\text { management of patients in } 29 \% \text { of the cases, } \\
\text { because of additional lesions found; whether } \\
\text { this led to improved patient outcomes is not } \\
\text { known }\end{array}$ \\
\hline
\end{tabular}


Table 3. Continued

\begin{tabular}{|c|c|c|c|c|}
\hline Study & Type of Study & Study Population & $\mathrm{N}$ & Major Findings/Comments \\
\hline Rosen et al. ${ }^{32}$ & Retrospective & $\begin{array}{l}\text { Patients with locally advanced } \\
\text { breast cancer treated with } \\
\text { neoadjuvant therapy (paclitaxel, } \\
\text { doxorubicin, and breast } \\
\text { hyperthermia) }\end{array}$ & 21 & $\begin{array}{l}\text { Correlation with pathology equal to pathology/ } \\
\text { underestimate/overestimate MRI: } 57 \% / 10 \% / \\
33 \% \text { correlation coefficients were } 0.74 \text { for } \\
\text { MRI and } 0.65 \text { (statistically nonsignificant } \\
\text { trend); in contrast to some of the other } \\
\text { studies, MRI tended to overestimate the } \\
\text { residual tumor (ie, underestimate response) }\end{array}$ \\
\hline Hwang et al. ${ }^{33}$ & Retrospective & $\begin{array}{l}\text { Patients with histologically } \\
\text { confirmed diagnosis of DCIS }\end{array}$ & 51 & $\begin{array}{l}\text { MRI was } 97 \% \text { sensitive and } 58 \% \text { specific for } \\
\text { detecting residual disease compared with } \\
\text { histology; the sensitivity was significantly } \\
\text { better than the sensitivity of XRM for } \\
\text { residual disease; in addition MRI had a } \\
\text { significantly higher NPV compared to XRM }\end{array}$ \\
\hline Belli et al. ${ }^{34}$ & Prospective & $\begin{array}{l}\text { Patients with locally advanced } \\
\text { breast cancer being treated with } \\
\text { neoadjuvant chemotherapy }\end{array}$ & 45 & $\begin{array}{l}\text { MRI had a } 90.2 \% \text { sensitivity and a } 100 \% \\
\text { specificity for residual disease }\end{array}$ \\
\hline Cheung et al. ${ }^{35}$ & Prospective & $\begin{array}{l}\text { Patients with locally advanced } \\
\text { breast cancer being treated with } \\
\text { neoadjuvant chemotherapy }\end{array}$ & 33 & $\begin{array}{l}\text { Residual tumor on MRI correlated with } \\
\text { microscopic findings (correlation coefficient } \\
=0.982, P<.001)\end{array}$ \\
\hline Partridge et al. ${ }^{36}$ & Prospective & $\begin{array}{l}\text { Patients with invasive breast } \\
\text { cancer undergoing neoadjuvant } \\
\text { therapy with doxorubicin and } \\
\text { cyclophosphamide }\end{array}$ & 52 & $\begin{array}{l}\text { Decreased tumor enhancement } \\
\text { prechemotherapy and postchemotherapy } \\
(210 \% \text { vs } 166 \%, P<.001) ; \text { MRI had } \\
\text { correlation coefficient of } 0.89 \text { compared with } \\
\text { pathology whereas clinical examination had } \\
\text { coefficient of } 0.60\end{array}$ \\
\hline Kawashima et al. ${ }^{37}$ & Prospective & $\begin{array}{l}\text { Patients who underwent excisional } \\
\text { biopsy of breast lesion }\end{array}$ & 50 & $\begin{array}{l}\text { MRI in detection of residual disease: sensitivity } \\
66 \% \text {; specificity } 81 \% \text {; PPV } 72 \% \text {; NPV } 83 \% \text {; } \\
\text { accuracy } 63 \%\end{array}$ \\
\hline Drew et al. ${ }^{38}$ & Prospective & $\begin{array}{l}\text { Patients with locally advanced } \\
\text { breast cancer receiving } \\
\text { neoadjuvant therapy }\end{array}$ & 17 & $\begin{array}{l}\text { Dynamic CE MRI was } 100 \% \text { accurate in } \\
\text { assessing residual disease; CBE and XRM } \\
\text { were not sensitivity/specificity/PPV/NPV } \\
\text { CBE: } 50 \% / 86 \% / 83 \% / 55 \% \text { XRM: } 90 \% / 57 \% / \\
75 \% / 80 \%\end{array}$ \\
\hline Weatherall et al. ${ }^{39}$ & Retrospective & $\begin{array}{l}\text { Patients with breast cancer with } \\
\text { chemotherapy prior to surgery }\end{array}$ & 20 & $\begin{array}{l}\text { MRI demonstrated a correlation with pathology } \\
\text { (coefficient }=0.93 \text { ); coefficients for CBE and } \\
\text { XRM were } 0.72 \text { and } 0.63 \text {, respectively }\end{array}$ \\
\hline Frei et al. ${ }^{40}$ & Retrospective & Patients with excisional biopsy & 68 & $\begin{array}{l}\text { MRI sensitivity/specificity/PPV/NPV } \\
>7 \text { days postbiopsy: } 89 \% / 52 \% / 81 \% / 69 \% \\
>14 \text { days postbiopsy: } 88 \% / 58 \% / 82 \% / 69 \% \\
>21 \text { days postbiopsy: } 91 \% / 69 \% / 88 \% / 75 \% \\
>28 \text { days postbiopsy: } 92 \% / 75 \% / 92 \% / 75 \% \\
>35 \text { days postbiopsy: } 95 \% / 75 \% / 91 \% / 86 \% \\
>42 \text { days postbiopsy: } 94 \% / 75 \% / 89 \% / 86 \% \\
\text { The peak values for PPV and plateau for } \\
\text { specificity occurs at }>28 \text { days, after which the } \\
\text { improvement is not as much; therefore, this } \\
\text { may be the best time to perform the MRI as } \\
\text { the PPV of positive margins in this study was } \\
69 \% \text { compared to } 92 \% \text { for MRI at day } 28 \text {, } \\
\text { which may lead to breast-conserving surgery }\end{array}$ \\
\hline Trecate et al. ${ }^{41}$ & Prospective & $\begin{array}{l}\text { Patients with locally advanced } \\
\text { breast cancer receiving } \\
\text { chemotherapy }\end{array}$ & 30 & $\begin{array}{l}\text { MRI: sensitivity: } 96 \% \text {; specificity: } 75 \% \text {; PPV: } \\
\text { 92.5\%; NPV 66\%; accuracy } 90 \%\end{array}$ \\
\hline Orel et al. ${ }^{42}$ & Prospective & $\begin{array}{l}\text { Patients who underwent excisional } \\
\text { biopsy }\end{array}$ & 47 & $\begin{array}{l}\text { MRI had PPV of } 82 \% \text { and NPV of } 61 \% \text {; false } \\
\text { negatives possibly secondary to postsurgical } \\
\text { changes }\end{array}$ \\
\hline Soderstrom et al. ${ }^{43}$ ) & Prospective & $\begin{array}{l}\text { Patients who underwent excisional } \\
\text { biopsies }\end{array}$ & 19 & $\begin{array}{l}\text { MRI had an } 84 \% \text { accuracy in determining } \\
\text { whether residual tumor was present in } \\
\text { patients postexcisional biopsy }\end{array}$ \\
\hline
\end{tabular}

which did not. A mean follow up of approximately 40 months in both groups demonstrated that the rate of recurrent tumor in the same breast was $1.2 \%$ and $6.8 \%$ in the group who had preoperative MRI and the control group $(P<.001)$, respectively. In addition, detection of contralateral breast cancer 
was $1.7 \%$ and $4 \%$ in the preoperative MRI group and the control group $(P<.001)$, respectively. ${ }^{44}$

\section{Occult Breast Cancers with Positive Nodes/Metastasis}

A number of studies have shown MRI to be useful in the identification of occult (ie, by mammography) breast cancers in patients who present with a metastatic pattern compatible with breast cancer (Table 4). ${ }^{1,45-47}$

\section{Breast Implant Rupture}

MRI is currently widely accepted in the realm of breast imaging as a diagnostic tool for the detection of implant rupture in women who have had breast augmentation. It is considered by some to be the diagnostic test of choice in this scenario. ${ }^{13}$ It has higher sensitivity and similar specificity to ultrasound in detecting silicone implant rupture. ${ }^{48}$ Current accepted uses of MRI in breast imaging are summarized in Table 1.

\section{MRI As a Screening Tool for Breast Cancer}

Currently, MRI is not widely used as a screening tool for breast cancer. This is due to various factors, including the increased cost when compared with mammography and ultrasound, the lack of adequate studies to justify this increased cost, and the variable specificity of MRI with regards to the breast. Although MRI is extremely sensitive for most invasive cancers, it tends to be less specific. One may think that screening younger women with denser breasts with MRI may help with early detection of breast cancer. However, in this age group, the incidence of breast cancer is less than 1 in 10,000 . In addition, as many as $30 \%$ of these patients will have benign disease. Because of the low specificity of MRI, in women with a low risk of having a breast cancer (eg, no family history, etc), most of the lesions picked up with MRI would be therefore be benign, resulting in a tremendous increase in unnecessary biopsies. ${ }^{1}$

However, in women at highest risk for breast cancer, such as those with suspected or known genetic mutations (eg, BRCA 1 and 2), MRI may be useful as a screening tool. There is, however, controversy on whether MRI should be offered to these women as the primary screening tool given the fact that in some instances, mammography may detect certain lesions with more accuracy, eg, DCIS lesions.

Women with BRCA mutations tend to develop breast cancer at a younger age, when breast density is higher. Breast cancers related to BRCA 1 (as opposed to BRCA 2) mutation tend NOT to be associated with DCIS and its subsequent microcalcifications, further decreasing detection by mammography. BRCA 1 associated tumors also tend to present with a more benign appearance on mammography, with round/pushing as opposed to irregular margins. However, with BRCA 2 carriers in whom DCIS is more prevalent, mammography, which can detect microcalcifications, is a valuable screening tool. ${ }^{49}$

Table 4. MRI in Occult Breast Cancer

\begin{tabular}{|c|c|c|c|c|c|}
\hline Study & Type of Study & Study Population & $\mathrm{N}$ & $\begin{array}{c}\text { Mean } \\
\text { Age/Range }\end{array}$ & Major Findings/Comments \\
\hline Olson et al. ${ }^{45}$ & Prospective & $\begin{array}{l}\text { Women with unknown primary } \\
\text { and metastatic axillary } \\
\text { adenocarcinoma; initial XRM, } \\
\text { US, or PE was not diagnostic of } \\
\text { malignancy }\end{array}$ & 40 & 58 & $\begin{array}{l}(+) \text { MRI correlated with breast } \\
\text { tumor in } 81 \% \text { of cases overall; } \\
\text { initial XRM, US, or PE was not } \\
\text { diagnostic of malignancy }\end{array}$ \\
\hline $\begin{array}{l}\text { Henry-Tillman RS } \\
\text { et al. (Dec 1999) } \\
\quad(54)\end{array}$ & Retrospective & $\begin{array}{l}\text { Patients with unknown primary, } \\
(+) \text { axillary/supraclavicular } \\
\text { lymphadenopathy, }(-) \text { XRM/ } \\
\text { CBE, and }(+) \text { MRI }\end{array}$ & 10 & 36 to 68 & $\begin{array}{l}\text { MRI was } 100 \% \text { accurate when } \\
\text { correlated with pathology; } 80 \% \\
(\mathrm{~N}=8) \text { were }(+) \text { and primary } \\
\text { breast CA was confirmed; } 20 \% \\
(\mathrm{~N}=2) \text { were negative and } \\
\text { other primaries (ovarian CA and } \\
\text { lymphoma) were identified }\end{array}$ \\
\hline $\begin{array}{l}\text { Orel SG et al. } \\
\quad \text { (Aug 1999) (55) }\end{array}$ & Prospective & $\begin{array}{l}\text { Patients with }(+) \text { axillary node } \\
\text { metastasis, negative PE and } \\
\text { XRM, and unknown primary }\end{array}$ & 22 & 49 & $\begin{array}{l}\text { Breast cancer was detected as the } \\
\text { primary in } 86 \%(\mathrm{~N}=19) \text { of } \\
\text { cases; } 17 \text { were confirmed by } \\
\text { pathology; } 2 \text { resolved on MRI } \\
\text { follow-up during chemotherapy }\end{array}$ \\
\hline
\end{tabular}


Table 5. MRI as a Screening Tool in High Risk Women

\begin{tabular}{|c|c|c|c|c|c|}
\hline Study & Type of Study & Study Population & $\mathrm{N}$ & $\begin{array}{l}\text { Mean } \\
\text { Age/Range }\end{array}$ & Major Findings/Comments \\
\hline Leach et al. ${ }^{55}$ & Prospective & $\begin{array}{l}\text { Women at high risk for breast } \\
\text { cancer (BRCA 1, 2, or TP53 } \\
\text { mutation, 1st degree relative } \\
\text { with mutation, family history of } \\
\text { breast/ovarian CA, family } \\
\text { history of Li-Fraumeni } \\
\text { syndrome) }\end{array}$ & 649 & 31 to 55 & $\begin{array}{l}\text { Sensitivity for CE MRI and XRM } \\
\text { was } 77 \% \text { and } 40 \% \text {, respectively; } \\
\text { specificity for CE MRI and } \\
\text { XRM was } 81 \% \text { and } 93 \% \text {, } \\
\text { respectively; sensitivity and } \\
\text { specificity for both methods } \\
\text { combined was } 94 \% \text { and } 77 \% \text {, } \\
\text { respectively; sensitivity of CE } \\
\text { MRI for BRCA } 1 \text { and BRCA } 2 \\
\text { were } 92 \% \text { and } 58 \%, \\
\text { respectively }\end{array}$ \\
\hline Lehman et al. ${ }^{56}$ & Prospective & $\begin{array}{l}\text { Women } \geq 25 \text { with high familial or } \\
\text { genetic risk of breast cancer }\end{array}$ & 367 & 40 & $\begin{array}{l}\text { 1.1\% of patients screened with } \\
\text { MRI had breast cancer by } \\
\text { pathology as opposed to } 0.3 \% \\
\text { by XRM (difference not } \\
\text { statistically significant); PPV of } \\
\text { biopsies performed as a result of } \\
\text { MRI was } 17 \%(4 / 24) \text {; PPV of } \\
\text { biopsies performed as a result of } \\
\text { XRM was } 25 \%(1 / 4)\end{array}$ \\
\hline Sim et al. ${ }^{58}$ & Retrospective & $\begin{array}{l}\text { Women who were at least at } 15 \% \\
\text { greater risk for breast cancer } \\
\text { (Claus model) }\end{array}$ & 179 & & $\begin{array}{l}\text { Sensitivity for MRI, XRM, and } \\
\text { US were } 93.3 \%, 83.3 \% \text {, and } \\
53.9 \% \text {, respectively; specificity } \\
\text { for MRI, XRM, and US were } \\
63.6 \%, 65.5 \% \text {, and } 85.7 \% \text {, } \\
\text { respectively; the sensitivity and } \\
\text { specificity for combined XRM } \\
\text { and US was } 92.9 \% \text { and } 62.5 \% \text {, } \\
\text { respectively }\end{array}$ \\
\hline Kriege et al. ${ }^{50}$ & Prospective & $\begin{array}{l}\text { Women who were at least at } 15 \% \\
\text { greater risk for breast cancer } \\
\text { due to familial or genetic } \\
\text { factors (Claus model) }\end{array}$ & 1909 & 40 & $\begin{array}{l}\text { Sensitivity for MRI in detecting } \\
\text { invasive breast cancer as } \\
\text { opposed to CBE and XRM was } \\
79.5 \%, 17.9 \% \text {, and } 33.3 \% \text {, } \\
\text { respectively; specificity for MRI, } \\
\text { CBE, and XRM was } 89.8 \% \text {, } \\
98.1 \% \text {, and } 95.0 \% \text {, respectively }\end{array}$ \\
\hline Morris et al. ${ }^{54}$ & Retrospective & $\begin{array}{l}\text { Women at high risk for breast } \\
\text { cancer (past history, family } \\
\text { history, LCIS, atypia) with } \\
\text { negative XRM }\end{array}$ & 367 & 50 & $\begin{array}{l}4 \% \text { of screened patients had } \\
\text { breast cancer by pathology } \\
\text { ( } 57 \% \text { were DCIS); percentage } \\
\text { was higher in those women with } \\
\text { past and family history ( } 8 \%) \text {, } \\
\text { PPV } 50 \% \text {; PPV of biopsy was } \\
24 \%\end{array}$ \\
\hline Warner et al. ${ }^{49}$ & Prospective & $\begin{array}{l}\text { Women who were carriers of } \\
\text { BRCA } 1 \text { and/or BRCA } 2\end{array}$ & 236 & 25 to 65 & $\begin{array}{l}\text { Sensitivity for MRI as opposed to } \\
\text { XRM, US, and CBE were } 77 \% \text {, } \\
36 \%(P=.02), 33 \% \text { ( } P= \\
.006) \text {, and } 9.1 \% \text {, respectively; } \\
\text { specificity for MRI, XRM, US, } \\
\text { and CBE were } 95.4 \%, 99.8 \% \text {, } \\
96 \%, \text { and } 99.3 \% \text {, respectively; } \\
\text { when all modalities were } \\
\text { combined there was a sensitivity } \\
\text { of } 95 \% \text { as opposed to } 45 \% \text { with } \\
\text { XRM and CBE combined }\end{array}$ \\
\hline Podo et al. ${ }^{57}$ & Prospective & $\begin{array}{l}\text { Women with confirmed BRCA } 1 \\
\text { or BRCA } 2 \text { mutations or with a } \\
1 \text { in } 2 \text { chance of having the } \\
\text { mutation }\end{array}$ & 105 & 55.3 & $\begin{array}{l}8 \text { breast cancers were identified } \\
\text { (all by CE MRI); only } 1 \text { was } \\
\text { detected by XRM and US; total } \\
\text { incidence of breast cancer was } \\
7.6 \%\end{array}$ \\
\hline
\end{tabular}

One major factor limiting the widespread use of MRI is the lack of commercial availability for MRI guided needle biopsy systems. However, MRI guided biopsy systems have been developed and are reported in the literature. In addition, as indicated above, the cost may be prohibitive. ${ }^{16,50}$ It may be 
nearly 10 times greater ( $\$ 1000$ compared with between $\$ 72$ and $\$ 160$ and $\$ 75$ and $\$ 300$ for MRI, mammography, and breast ultrasound, respectively). ${ }^{13,51-53}$

A number of studies have been performed looking at the utility of MRI as a screening tool in women at high risk of breast cancer. Warner et al, studying 236 women with BRCA mutations demonstrated that MRI combined with ultrasonography and mammography had a sensitivity of $95 \%$, compared with only $45 \%$ when using clinical breast exams and mammography alone. ${ }^{49}$ Kriege et al demonstrated that MRI in high risk women (ie, those with a familial or genetic risk for breast cancer) had a higher sensitivity but lower specificity than mammography. Mammography, however, had a higher sensitivity than MRI for detecting DCIS, suggesting that a combination approach may be the best. ${ }^{50} \mathrm{~A}$ summary of several of the major studies is presented in Table 5. ${ }^{49,50,54-58}$

In light of the studies exploring the use of MRI in the screening of high risk women, some researchers have explored the effect of more intensive screening protocols on patient anxiety and quality of life. Studies by Warner and Rijnsburger et al have demonstrated no adverse effect of increased surveillance on anxiety, depression, distress, and quality of life. ${ }^{59,60}$

Except for in patients with breast implants, both mammography and ultrasound should be performed in all patients, even if an MRI examination is performed. In addition, the evaluation of the patient should take into account not only these results but also clinical findings, ie, from clinical breast examinations. ${ }^{5}$

\section{Conclusion}

The utility of MRI in breast imaging has undergone much advancement in the last 25 years. It shows promise in many areas, including staging of breast cancers, determination of tumor size and spread, and may be a valuable screening tool for those patients with a high risk of breast cancer. It may also be of value in those patients whose breasts that are too dense for mammography, as high breast density has been shown to only minimally affect MRI sensitivity. ${ }^{6}$ Various studies have demonstrated that although the sensitivity of MRI in detection of breast cancer is high, the specificity of this technique varies. ${ }^{6}$ In addition, many studies have demonstrated the highest sensitivity and specificity when using a combination approach, ie, using $\mathrm{X}$ ray mammography, ultrasound, and MRI together when evaluating patients, especially for those who are at high risk for breast cancer. Further studies are needed to elucidate the exact role of MRI in the realm of breast imaging.

\section{References}

1. Rankin SC. MRI of the breast. Br J Radiol 2000;73: 806-18.

2. Majid AS, de Paredes ES, Doherty RD, et al. Missed breast carcinoma: pitfalls and pearls. Radiographics. 2003;23:881-95.

3. Doi K, MacMahon H, Katsuragawa S, et al. Computer-aided diagnosis in radiology: potential and pitfalls. Eur J Radiol 1997;31:97-109.

4. Plevritis SK, Ikeda DM. Ethical issues in contrastenhanced magnetic resonance imaging screening for breast cancer. Top Magn Reson Imaging 2002;13: $79-84$.

5. Heywang-Kobrunner SH, Viehweg P, Heinig A, Kuchler C. Contrast-enhanced MRI of the breast: accuracy, value, controversies, solutions. Eur J Radiol 1997;24:94-108.

6. Bluemke DA, Gatsonis CA, Chen MH, et al. Magnetic resonance imaging of the breast prior to biopsy. JAMA 2004;292:2375-742.

7. Brant WE. Diagnostic imaging methods. In: Brant WE, Helms CA, editors. Fundamentals of Diagnostic Radiology, 2nd ed. Philadelphia (PA): Lippincott Williams and Wilkins; 1999. p. 19.

8. Ose K, Doue T, Zen K, et al. Gadolinium as an alternative to iodinated contrast media for $\mathrm{x}$-ray angiography in patients with severe allergy. Circ J 2005;69:507-9.

9. Sam AD II, Morasch MD, Collins J, et al. Safety of gadolinium contrast angiography in patients with chronic renal insufficiency. J Vasc Surg 2003;38: 313-8.

10. Thomsen HS. Gadolinium-based contrast media may be nephrotoxic even at approved doses. Eur Radiol 2004;14:1654-6.

11. Morris EA. Breast cancer imaging with MRI. Radiol Clin North Am 2002;40:443-66.

12. Iglehart DJ, Kaelin CM. Diseases of the breast. In: Townsend CM, Beauchamp RD, Evers BM, Mattox KL, editors. Sabiston Textbook of Surgery 17 th ed. Philadelphia (PA): Elsevier; 2004. p. 867.

13. Feig SA, Orel SG, Dershaw DD. The breast. In: Grainger RG, Allison D, Adam A, Dixon AK, editors. Grainger \& Allison's Diagnostic Radiology: A Textbook of Medical Imaging, 4th ed. Orlando (FL): Churchill Livingstone; 2001. p. 2268-72.

14. Kinkel K, Hylton N. Challenges to interpretation of breast MRI. J Magn Reson Imaging 2001;13:821-9. 
15. Schnall MD, Ikeda DM. Lesion diagnosis working group report. J Magn Reson Imaging 1999;10:98290.

16. Kinkel K, Vlastos G. MR imaging: breast cancer staging and screening. Semin Surg Oncol 2001;20: 187-96.

17. Schelfout K, Van Goethem M, Kersschot E, et al. Contrast-enhanced MR imaging of breast lesions and effect on treatment. Eur J Surg Oncol 2004;30: 501-7.

18. Bedrosian I, Mick R, Orel SG, et al. Changes in the surgical management of patients with breast carcinoma based on preoperative magnetic resonance imaging. Cancer 2003;98:468-73.

19. Riber A, Schirrmeister H, Gabelmann A, et al. Preoperative staging of invasive breast cancer with MR mammography and/or PET: boon or bunk? Br J Radiol 2002;75:789-98.

20. Fischer U, Kopka L, Grabbe E. Breast carcinoma: effect of preoperative contrast-enhanced MR imaging on the therapeutic approach. Radiology 1999; 213:881-8.

21. Esserman L, Hylton N, Yassa L, et al. Utility of magnetic resonance imaging in the management of breast cancer: evidence for improved preoperative staging. J Clin Oncol 1999;17:110-9.

22. Rodenko GN, Harms SE, Pruneda JM, et al. MR imaging in the management before surgery of lobular carcinoma of the breast: correlation with pathology. AJR 1996;167:1415-9.

23. Boetes C, Veltman J, van Die L, et al. The role of MRI in invasive lobular carcinoma. Breast Cancer Res Treat 2004;86:31-7.

24. Van Goethem M, Schelfout K, Dijckmans L, et al. MR mammography in the preoperative staging of breast cancer in patients with dense breast tissue: comparison with mammography and ultrasound. Eur Radiol 2004;14:809-16.

25. Yeh E, Slanetz P, Kopans DB, et al. Prospective comparison of mammography, sonography, and MRI in patients undergoing neoadjuvant chemotherapy for palpable breast cancer. AJR 2005;184: $868-77$.

26. Chen X, Moore MO, Lehman CD, et al. Combined use of MRI and PET to monitor response and assess residual disease for locally advanced breast cancer treated with neoadjuvant chemotherapy. Acad Radiol 2004;11:1115-24.

27. Denis F, Desbiez-Bourcier AV, Chapiron C, et al. Contrast enhanced magnetic resonance image underestimates residual disease following neoadjuvant docetaxel based chemotherapy for breast cancer. Eur J Surg Oncol 2004;30:1069-76.

28. Tozaki M, Uno S, Kobayashi T. Histologic breast cancer extent after neoadjuvant chemotherapy: comparison with multidetector-row CT and dynamic MRI. Radiat Med 2004;22:246-53.

29. Bodini M, Berruti A, Bottini A, et al. Magnetic res- onance imaging in comparison to clinical palpation in assessing the response of breast cancer to epirubicin primary chemotherapy [abstract]. Breast Cancer Res Treat 2004;85:211-8.

30. Warren RM, Bobrow LG, Earl HM, et al. Can breast MRI help in the management of women with breast cancer treated by neoadjuvant chemotherapy? Br J Cancer 2004;90:1349-60.

31. Lee JM, Orel SG, Czerniecki BJ, et al. MRI before reexcision surgery in patients with breast cancer. AJR 2004; 182:473-80.

32. Rosen EL, Blackwell KL, Baker JA, et al. Accuracy of MRI in the detection of residual breast cancer after neoadjuvant chemotherapy. AJR 2003;181:1275-82.

33. Hwang ES, Kinkel K, Esserman LJ, et al. Magnetic resonance imaging in patients diagnosed with ductal carcinoma-in-situ: value in the diagnosis of residual disease, occult invasion, and multicentricity. Ann Surg Oncol 2003;10:381-8.

34. Belli P, Romani M, Costantini M, et al. Role of magnetic resonance imaging in the pre and postchemotherapy evaluation in locally advanced breast carcinoma [abstract]. Rays 2002;27:279-90.

35. Cheung YC, Chen SC, Su MY, et al. Monitoring the size and response of locally advanced breast cancer to neoadjuvant chemotherapy (weekly paclitaxel and epifubicin) with serial enhanced MRI. Breast Cancer Res Treat 2003;78:51-8.

36. Partridge SC, Gibbs JE, Lu Y, et al. Accuracy of MR imaging for revealing residual breast cancer in patients who have undergone neoadjuvant chemotherapy. AJR 2002;179:1193-9.

37. Kawashima H, Tawara M, Suzuki M, et al. Effectiveness of dynamic MRI for diagnosing pericicatricial minimal residual breast cancer following excisional biopsy. Eur J Radiol 2001;40:2-9.

38. Drew PJ, Kerin MJ, Mahapatra T, et al. Evaluation of response to neoadjuvant chemoradiotherapy for locally advanced breast cancer with dynamic contrast-enhanced MRI of the breast. Eur J Surg Oncol 2001;27:617-20.

39. Weatherall PT, Evans GF, Metzger GJ. MRI vs. histologic measurement of breast cancer following chemotherapy: comparison with x-ray mammography and palpation. J Magn Reson Imaging 2001;13: $868-75$.

40. Frei KA, Kinkel K, Boenl HM, et al. MR imaging of the breast in patients with positive margins after lumpectomy: influence of the time interval between lumpectomy and MR imaging. AJR 2000;175:157784.

41. Trecate G, Ceglia E, Stabile F, et al. Locally advanced breast cancer treated with primary chemotherapy: comparison between magnetic resonance imaging and pathological evaluation of residual disease [abstract]. Tumori 1999;85:220-8.

42. Orel Sg, Reynolds C, Schnall MD, et al. Breast 
carcinoma: MR imaging before re-excisional biopsy. Radiology 1997;205:429-36.

43. Soderstrom CE, Harms SE, Farrell RS, et al. Detection with MR imaging of residual tumor in the breast soon after surgery. AJR 1997;168:485-8.

44. Fischer U, Zachariae O, Baum F, et al. The influence of preoperative MRI of the breasts on recurrence rate in patients with breast cancer [abstract]. Eur Radiol 2004;14:1725-31.

45. Olson JA, Jr., Morris EA, Van Zee KJ, et al. Magnetic resonance imaging facilitates breast conservation for occult breast cancer. Ann Surg Oncol 2000; 7:411-5.

46. Henry-Tillman RS, Harms SE, Westbrook KC, et al. Role of breast magnetic resonance imaging in determining breast as a source of unknown metastatic lymphadenopathy. Am J Surg 1999;178:496500.

47. Orel SG, Weinstein SP, Schnall MD, et al. Breast MR imaging in patients with axillary node metastases and unknown primary malignancy. Radiology 1999; 212:543-9.

48. Lindfors KK. Breast imaging. In: Brant WE, Helms CA, editors. Fundamentals of Diagnostic Radiology, 2nd ed. Philadelphia (PA): Lippincott Williams and Wilkins; 1999. p. 493, 512-3.

49. Warner E, Plewes DB, Hill KA, et al. Surveillance of BRCA1 and BRCA2 mutation carriers with magnetic resonance imaging, ultrasound, mammography, and clinical breast examination. JAMA 2004;292:131725.

50. Kriege M, Brekelmans CT, Boetes C, et al. Efficacy of MRI and mammography for breast-cancer screening in women with a familial or genetic predisposition. N Engl J Med 2004;351:427-37.

51. Imaginis. Magnetic resonance breast imaging (MRI,
MR). May 2005. Available at: http://imaginis.com/ breasthealth/mri.asp. Accessed on: June 3, 2005.

52. Breast Cancer Action. Newsletter \#39-December 1996/January 1997. Available at: http://www. bcaction.org/Pages/SearchablePages/1996Newsletters/ Newsletter039G.html. Accessed on: June 3, 2005.

53. Mettler FA. Essentials of Radiology, 2nd ed. Philadelphia (PA): Elsevier; 2005. p. 401.

54. Morris EA, Liberman L, Ballon DJ, et al. MRI of occult breast carcinoma in a high risk population. AJR 2003;181:619-26.

55. Leach MO, Boggis CR, Dixon AK, et al. Screening with magnetic resonance imaging and mammography of a UK population at high familial risk of breast cancer: a prospective multicentre cohort study (MARIBS). Lancet 2005;365:1679-78.

56. Lehman CD, Blume JD, Weatherall P, et al. Screening women at high risk for breast cancer with mammography and magnetic resonance imaging. Cancer. 2005;103:1898-905.

57. Podo F, Sardanelli F, Canese R, et al. The Italian multi-centre project on evaluation of MRI and other imaging modalities in early detection of breast cancer in subjects at high genetic risk [abstract]. J Exp Clin Cancer Res 2002;21(3 Suppl):115-24.

58. Sim LS, Hendriks JH, Fook-Chong SM. Breast ultrasound in women with familial risk of breast cancer. Ann Acad Med Singapore. 2004;33:600-6.

59. Warner E. Intensive radiologic surveillance: a focus on the psychological issues [abstract]. Ann Oncol 2004;15 Suppl 1:143-7.

60. Rijnsburger AJ, Essink-Bot ML, van Dooren S, et al. Impact of screening for breast cancer in high-risk women on health-related quality of life. Br J Cancer. 2004;91:69-76. 